\title{
Pengaruh atribut produk dan layanan lembaga pembiayaan terhadap keputusan pembelian sepeda motor Honda Vario di Kota Jambi
}

\author{
Bestina Sri Juniar*; Johannes; Sigit Indrawijaya \\ Program Studi Manajemen Fakultas Ekonomi dan Bisnis Universitas Jambi \\ *E-mail korepondensi: bestina.srijuniar@yahoo.com
}

\begin{abstract}
This study aims to explain the influence of financial institution product and service attributes on purchasing decisions of Honda Vario Jambi motorbikes in Jambi City. The sample is 140 users of Honda Vario motorcycles, with the sampling technique used is Purposive sampling. Validity and reliability test results show that the research instrument is valid and reliable. The data analysis used in this study is multiple linear regression analysis using SPSS Version 22 software. The results show that purchasing decisions are influenced by the financial product and service attributes significantly and partially the decision to purchase Honda vario motorcycles in Jambi City is influenced by attributes financial institution products and services. In the discussion, the results of the study showed that the presence of product attributes and services of financial institutions could increase sales of Honda Vario motorcycles. To achieve this level of sales, the company must continue to present superior product attributes and maintain good cooperative relations with financing institutions that provide financial institution services.
\end{abstract}

Keywords: product attributes, financing agency services, purchasing decisions

\begin{abstract}
Abstrak
Penelitian ini bertujuan untuk menjelaskan pengaruh atribut produk dan layanan lembaga pembiayaan terhadap keputusan pembelian sepeda motor Honda Vario jambi di Kota Jambi. Sampelnya adalah pengguna motor Honda Vario sebanyak 140 responden, dengan teknik pengambilan sampel yang digunakan adalah Purposive sampling. Hasil uji validitas dan reliabilitas menunjukkan bahwa instrumen penelitian valid dan reliabel. Analisis data yang digunakan dalam penelitian ini adalah analisis regresi linier berganda dengan menggunakan software SPSS Versi 22. Hasil penelitian menunjukkan bahwa keputusan pembelian dipengaruhi oleh atribut produk dan layanan lembaga pembiayaan secara signifikan dan secara parsial keputusan pembelian sepeda motor honda vario di Kota Jambi dipengaruhi oleh atribut produk dan layanan lembaga pembiayaan. Pada pembahasan, hasil penelitian menunjukkan bahwa dengan adanya atribut produk dan layanan lembaga pembiayaan dapat meningkatkan penjualan sepeda motor Honda Vario. Untuk mencapai pada tingkat penjualan tersebut maka perusahaan harus tetap mempertankan atribut produk yang lebih unggul dan menjaga hubungan kerja sama yang baik terhadap lembaga pembiayan yang memberikan layanan lembaga pembiayaan.
\end{abstract}

Kata kunci : atribut produk, layanan lembaga pembiayaan, keputusan pembelian

\section{PENDAHULUAN}

Sepeda motor adalah salah satu alat transportasi yang digunakan untuk memudahkan aktivitas sehari-sehari. Sepeda motor dianggap lebih praktis dan lebih mudah menerjang kemacetan. Pradana dan Relawan (2017) mengemukakan kebutuhan masyarakat akan sarana transportasi pada saat ini sangat penting terutama sarana 
transportasi yang memadai, hal ini dipicu oleh perkembangan jaman yang menuntut manusia untuk dapat bergerak lebih mudah dalam mencapai tujuan dalam aktivitas kesehariannya.

Kondisi kebutuhan konsumen membuat AHM (Astra Honda Motor) selalu menciptakan inovasi akan produk yang dihasilkan guna memenuhi sepeda motor yang sesuai dengan kebutuhan konsumen dari berbagai kalangan (Rahayu, 2015). Agar perusahaan dapat mencapai tujuan yang telah ditetapkan, maka diperlukan strategi yang maksimal dalam usaha meningkatkan penjualan. Strategi tersebut adalah dengan mencermati permintaan konsumen terhadap suatu barang. Pemahaman terhadap kebutuhan dan keinginan konsumen merupakan dasar bagi suatu perusahaan dalam mencapai keberhasilan pemasaran produk/jasa mereka, karena pemasaran merupakan kegiatan yang diarahkan untuk memuaskan kebutuhan dan keinginan konsumen (Khristiawan, 2014).

Keputusan pembelian suatu produk akan melibatkan atribut produk, branding, kemasan, pelabelan, dan layanan pendukung produk. Perusahaan juga mengembangkan layanan pendukung produk yang meningkatkan layanan dan kepuasan pelanggan dan perlindungan terhadap pesaing (Kotler, P. dan Armstrong,G., 2016). Atribut Produk merupakan sesuatu yang melekat pada suatu produk. Atribut produk memegang peran yang sangat vital, karena atribut produk merupakan salah satu faktor yang dijadikan bahan pertimbangan oleh konsumen ketika akan membeli produk tersebut. Menurut Suatma (2013) Kualitas produk adalah kemampuan suatu produk dalam memberikan kinerja sesuai dengan fungsinya. Berikut adalah data penjualan sepeda motor domestik Indonesia, periode 2016 :

Tabel 1. Penjualan Sepeda Motor Tahun 2016

Pabrikan Terjual (Unit) Persentase

\begin{tabular}{lcc}
\hline Honda & 4.380 .888 & 73,86 \\
Yamaha & 1.394 .078 & 23,50 \\
Kawasaki & 97.622 & 1,65 \\
Suzuki & 56.824 & 0,96 \\
TVS & 1.873 & 0,03 \\
Total & 5.931 .285 & 100
\end{tabular}

Sumber : AISI (Asosiasi Industri Sepeda Motor Indonesia)

Data pada Tabel 1 dapat diketahui Honda menjadi merek yang paling tinggi persentase penjualannya. Honda sebagai perusahaan otomotif yang sedang berkembang saat ini telah menyadari persaingan ini. Di Indonesia banyak terdapat distributor produk Honda. Disamping banyak menjual berbagai jenis sepeda motor, Honda juga memiliki banyak distributor yang membuka bengkel dan menjual spare part sepeda motor Honda.

Honda pada jenis matic pada tahun 2016 menjadi jenis yang sangat diminati karena termasuk kedalam daftar tebel 10 besar merek dan jenis sepeda motor yang paling banyak diminati, seperti Tabel 2.

Berdasarkan Tabel 2 ternyata Honda Beat mampu mengalahkan tingkat penjualan motor Honda Vario. Pada kenyataan Vario yang lebih dulu di kenalkan pada masyarakat akhirnya berjalan seiring waktu Honda Beat mampu mempengaruhi konsumen dalam keputusan pembelian. Keunggulan atribut produk masing-masing produk Motor Honda 
tersebut berbeda sehingga menimbulkan persepsi yang berbeda bagi konsumen. Nilai konsumen yang dirasakan sangat jelas atribut produk Honda Vario yang memiliki keunggulan yang lebih daripada Honda Beat tetapi tingkat penjualan selalu naik turun, tidak ada kenaikkan yang signifikan.

Tabel 2 Data penjualan motor honda di Tahun 2016

\begin{tabular}{clc}
\hline Segmen (Total) & Produk & Terjual (Unit) \\
\hline Skuter (3.661.284 unit) & Beat series & 1.814 .600 \\
& Vario Series & 1.306 .600 \\
& Scoopy F1 & 528.622 \\
& Pcx 150 & 5.292 \\
& Spacy & 6.170 \\
Bebek & Revo F1 & 159.465 \\
401.601 unit) & Supra Series & 184.302 \\
& Blade 125 & 20.139 \\
& Sonic 150 R & 37.695 \\
& All New CB150R & 152.263 \\
& All New CBR150R & 87.554 \\
Sport (318.000 unit) & Verza & 71.231 \\
& Megapro & 4.018 \\
& CBR250RR & 2.698 \\
& Big Bike & 236 \\
\hline
\end{tabular}

Sumber : AISI (Asosiasi Industri Sepeda Motor Indonesia)

Hal ini sejalan dengan penelitian yang di lakukan oleh Patria Adi Perdana, dan Ida N Relawan (2017) menunjukkan bahwa adanya pengaruh atribut produk (Kualitas Produk, Fitur, Desain, Harga, Merek) juga berpengaruh terhadap keputusan pembelian, tapi yang sangat berpengaruh dari semua variabel adalah merek terhadap keputusan pembelian. Semakin menarik dan iovatif atribut produk yang dibuat maka pelanggan akan yakin dengan produk tersebut, sehingga untuk melakukan keputusan pembelian tidak melalui banyak pertimbangan.

Meningkatnya mobilitas masyarakat pada era modern saat ini membuat kebutuhan akan kendaraan khususnya roda dua juga mengalami peningkatan pembelian. Namun kebutuhan pembelian tersebut tidak disertai dengan peningkatan pendapatan ekonomi sosial masyarakat di Indonesia. Sehingga hal tersebut menyebabkan banyak munculnya perusahaan pembiayaan konsumen untuk mememberikan solusi bagi masyarakat menengah kebawah yang membutuhkan bantuan dalam pembiayayaan pengadaan barang. Dengan adanya perusahaan pembiayaan konsumen tersebut masyarakat yang tidak memiliki dana cukup untuk membeli suatu barang tetap dapat melakukan pembelian dengan system pembayaran secara angsuran (Saragih, 2013).

Menurut Setiaji (2010) pembiayaan merupakan salah satu model pembiyaan yang dilakukan oleh perusahaan finansial, disamping kegiatan seperti layanan lembaga pembiayaan, factoring, kartu kredit dan sebagainya. Pembiayaan timbul karena adanya kesepakatan antara dua pihak yaitu perusahaan pembiayaan dan konsumen. Dalam perjanjian ini menggunakan asas kebebasan berkontrak.

Menurut Nomanca (2012) mengatakan berdasarkan pengetahuan serta pemahaman yang baik terhadap suatu produk, konsumen menentukan pilihan produk apa yang akan 
dibeli atau digunakan. Menurut Bella Nomaca (2012) dalam penelitiannya yang mempengaruhi keputusan konsumen dalam menggunakan jasa lembaga pembiayaan (leasing) PT. Federal International Finance fif) Tanjung Batu Kundur yang tediri dari beberapa variabel (Kebutuhan dan Motivasi, Persepsi, Sikap dan Keyakinan, Kepribadian, Pengetahuan) yang sangat berpengaruh adalah variabel persepsi. layanan lembaga pembiayaan sejauh ini belum banyak dipergunakan dalam penelitian, padahal peran layanan lembaga pembiayaan menjadi salah satu pertimbangan bagi konsumen untuk melakukan pembelian selain melihat atribut produk yang melekat pada atribut itu sendiri. Peran lembaga pembiayaan ini sangat berpeluang besar bagi konsumen yang ingin membeli, juga dijadikan pertimbangan untuk konsumen membeli sepeda motor setelah melihat atribut produk yang melekat pada produk itu sendiri.Bagaimana pengaruh atribut produk dan layanan lembaga pembiayaan terhadap keputusan pembelian Sepeda motor Honda vario danApakah atribut produk berpengaruh dominan terhadap keputusan pembelian.

\section{TINJAUAN PUSTAKA}

\section{Produk}

Produk adalah segala sesuatu yang dapat ditawarkan produsen untuk diperhatikan, diminta, dicari dibeli, digunakan atau dikonsumsi pasar sebagai pemenuhan kebutuhan atau keinginan pasar yang bersangkutan (Tjiptono, 2008). Menurut Simamora (2001) produk adalah sesuatu yang dapat ditawarkan oleh individu, rumah tangga ataupun organisasi kedalam pasar untuk diperhatikan, digunakan, dibeli maupun dimiliki.

\section{Atribut produk}

Atribut produk adalah unsur-unsur produk yang dipandang penting oleh konsumen dan dijadikan sebagai dasar pengambilan keputusan pembelian Tjiptono (2008). Atribut produk meliputi merek, kemasan, jaminan (garansi), pelayanan dan sebagainya. Sedangkan menurut Simamora (2001) dalam bukunya Memenangkan Pasar dengan Pemasaran yang Efektif dan Profitabel, atribut produk adalah faktor faktor yang dipertimbangkan oleh pembeli pada saat membeli produk, seperti harga,kualitas, kelengkapan fungsi (fitur), desain, layanan purna jual, dan lain-lain. Menurut Kotler atribut mencangkup kualitas produk, fitur produk dan desain produk.

Layanan lembaga pembiayaan

Pengertian lembaga pembiayaan menurut keputusan Menteri Keuangan No.1169/KMK.01/1991 tanggal 21 september 1991 tentang kegiatan sewa guna usaha. Sewa guna usaha adalah kegiatan pembiayaan dalam bentuk penyediaan barang modal baik secara guna usaha dengan hak opsi (finance lease) maupun sewa guna usaha tanpa hak opsi (operating lease), untuk digunakan oleh lessee selama jangka waktu tertentu berdasarkan pembayaranberkala.

Adapun pengertian lessee dan lessor menurut keputusan Menteri KeuanganNo.1169/KMK.01/1991, adalah sebagai berikut: Lessee adalah perusahaan atau perorangan yang menggunakan barang modal dengan pembiayaan dari lessor. Lessor adalah perusahaan atau perusahaan sewa guna usaha yang melakukan kegiatan sewaguna usaha.

Selanjutnya yang dimaksudnya dengan finance lease adalah kegiatan sewa guna usaha dimana lessee pada akhir masa kontrak mempunyai hak opsi untuk membeli objek sewa guna usaha berdasarkan nilai sisa yang disepakati. Sebaliknya operating lease tidak mempunyai hak opsi untuk membeli objek sewa guna usaha.Tujuan Pelaksanaan Sewa Guna Usaha 


\section{Keputusan pembelian}

Pengambilan keputusan adalah kegiatan individu yang secara lngsung terlibat dalam mendapatkan dan mempergunakan barang yang ditawarkan. Keputusan pembelian merupakan kegiatan individu yang secara langsung terlibat dalam pengambilan keputusan untuk melakukan pembelian terhadap produk yang ditawarkan oleh penjual. Keputusan pembelian merupakan tahap dari proses keputusan pembeli yaitu ketika konsumen benarbenar membeli produk.

Dimana konsumen mengenal masalahnya, mencari informasi mengenai produk atau merk tertentu dan mengevaluasi seberapa baik masing-masing alternative tersebut dapat memecahkan masalahnya yang kemudian mengarah kepada keputusan pembelian (Kotler P, 2008).

Faktor yang mempengaruhi konsumen dalam melakukan pembelian suatu produk atau jasa, biasanya konsumen selalu mempertimbangkan kualitas, harga dan produk sudah yang sudah dikenal oleh masyarakat Sebelum konsumen memutuskan untuk membeli, biasanya konsumen melalui beberapa tahap terlebih dahulu yaitu: Pengenalan masalah, dalam tahap ini pembeli atau konsumen menyadari suatu masalah atau kebutuhan yang dipicu oleh rangsangan internal maupun eksternal. Pencarian informasi, konsumen sering mencari jumlah informasiyang terbatas. Sumber informasi konsumen terdiri dari pribadi, komersial, public, dan eksperimental. Evaluasi alternatif, konsumen berusaha memuaskan sebuah kebutuhan, konsumen mencari manfaat tertentudari solusi produk dan konsumen melihat masing-masing produk sebagai kelompok atribut dengan berbagai kemampuan untuk menghantarkan manfaat yang diperlukan untuk memuaskan kebutuhan yang konsumen butuhkan.

Keputusan membeli atau tidak, dalam tahap evaluasi, para konsumen membentuk preferensi atas merek-merek yang ada di dalam kumpulan pilihan. Konsumen juga dapat membentuk niat untuk membeli merek yang paling disukai.

Perilaku pasca pembelian, Setelah pembelian, konsumen mungkin mengalami ketidaksesuaian karena memerhatikan fitur-fitur tertentu yang mengganggu atau mendengar hal-hal yang menyenangkan tentang merek lain, dan akan selalu siaga terhadap informasi yang mendukung keputusannya. Komunikasi pemasaran harus memasok keyakinan dan evaluasi yang mengukuhkan pilihan konsumen dan membantu dia merasa nyaman dengan merek. Tugas pemasar tidak berakhir begitu saja ketika produk dibeli. Para pemasar harus memantau kepuasan pasca pembelian, tindakan pasca pembelian, dan pemakaian produk pasca pembelian.

\section{Kerangka pemikiran}

Kerangka pemikiran yang menjadi landasan dalam penulisan ini, ialah untuk mengetahui pengaruh Atribut produk dan layanan lembaga pembiayaan berpengaruh secara signifikan terhadap keputusan pembelian Sepeda motor Honda Vario dan variabel dominan terhadap keputusan pembelian.

\section{Hipotesis}

\section{Hubungan antara variabel atribut produk terhadap keputusan pembelian}

Produk adalah segala sesuatu yang dapat ditawarkan kedalam pasar untuk diperhatikan, dimiliki, dipakai atau dikonsumsi sehingga dapat memuaskan suatu keinginan/semua kebutuhan (Kotler dan Keller 2007). Sedangkan menurut Tjiptono (2008) atribut produk adalah unsur-unsur produk yang dipandang penting oleh konsumen dan dijadikan sebagai dasar pengambilan keputusan pembelian.

Menurut penelitian yang dilakukan oleh Wijaksono (2013) menunjukkan bahwa harga beli , pilihan warna, mesin, desain bodi dan keiritan bahan bakar secara simultan berpengaruh signifikan terhadap keputusan pembelian sepeda motor Yamaha Mio J pada 
Dealer Yamaha Supriadi Motor dengan arah positif dan harga beli, pilihan warna, mesin, desain bodi dan keiritan bahan bakar secara parsial berpengaruh signifikan terhadap keputusan pembelian sepeda motor Yamaha Mio J pada Dealer Yamaha Supriadi Motor dengan arah positif. Faktor-faktor yang dipertimbangkan oleh pembeli pada saat membeli produk, seperti harga,kualitas, kelengkapan fungsi (fitur), desain, layanan purna jual, dan lain-lain (Simamora (2001).

\section{Hubungan antar variabel layanan lembaga pembiayaan terhadap keputusan pembelian}

Menurut Bella Nomaca (2012) dalam penelitiannya yang mempengaruhi keputusan konsumen dalam menggunakan jasa leasing Pt. Federal International Finance fif) Tanjung Batu Kundur yang tediri dari beberapa variabel (Kebutuhan dan Motivasi, Persepsi, Sikap dan Keyakinan, Kepribadian, Pengetahuan) yang sangat berpengaruh adalah variabel persepsi. Layanan lembaga pembiayaan sejauh ini belum banyak dipergunakan dalam penelitian, padahal peran Layanan lembaga pembiayaan menjadi salah satu pertimbangan bagi konsumen untuk melakukan pembelian selain melihat atribut produk yang melekat pasa atribut itu sendiri.

\section{METODE}

\section{Populasi dan sampel}

Populasi penelitian ini adalah konsumen yang sudah melakukan pembelian pada produk Sepeda Motor merek Honda Vario, khususnya untuk daerah Kota Jambi.

Teknik pengambilan sampel pada penelitian ini adalah non-probability sampling. Nonprobability sampling adalah teknik pengambilan sampel yang tidak memberi peluang / kesempatan yang sama bagi setiap unsur atau anggota populasi untuk dipilih menjadi sampel. Salah satu teknik non-probability sampling yang digunakan oleh peneliti adalah Purposive Sampling atau Judgmental Sampling Penarikan sampel secara purposif merupakan cara penarikan sample yang dilakukan memilih subjek berdasarkan kriteria spesifik yang ditetapkan peneliti. Kriteria yaitu konsumen yang telah membeli sepeda motor Honda Vario dan informasi dari orang lain.

\section{Sumber data}

Data yang di kumpulkan melalui data primer dan data sekunder. Pengumpulan data primer diperoleh dengan cara wawancara dan penyebaran kuisioner terdahulu. Sumber nya adalah konsumen yang menjadi responden penelitian yaitu konsumen yang telah membeli produk motor merek Honda Vario. Sedangkan pengumpulan data sekunder dilakukan melalui penelitian kepustakaan yaitu memperoleh informasi literatur, internet, media online, dan laporan penelitian.

\section{Metode dan alat analisis data}

Teknik analisis data dilakukan menggunakan regresi linier berganda dengan bantuan program Statistical Package for Social Science (SPSS). Analisis regresi berganda digunakan untuk mengetahui ada tidaknya pengaruh Atribut Produk (X1) dan Layanan lembaga pembiayaan lembaga pembiayaan $\left(\mathrm{X}_{2}\right)$ terhadap Kepeutusan Pembelian (Y). Berdasarkan hal tersebut, persamaan regresi linier bergandanya yaitu:

$$
\mathbf{Y}=\mathbf{a}+\mathbf{p i X i}+32 \mathrm{X} 2+\mathbf{e}
$$

Keterangan:

$\mathrm{Y} \quad=$ Keputusan pembelian

a $\quad=$ Konstanta

$\mathrm{P}_{1}, \mathrm{P} 2=$ Koefisien regresi 


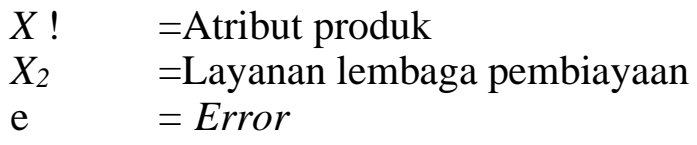

Untuk mengukur seberapa jauh kemampuan model menerangkan variasi variabel dependen, maka menggunakan nilai koefisien determinasi $\left(\mathrm{R}^{2}\right)$. Nilai $\mathrm{R}^{2}$ yang kecil berarti kemampuan variabel independen dalam menjelaskan variasi variabel dependen amat terbatas. Nilai yang mendekati satu berarti variabel independen memberikan hampir semua informasi yang dibutuhkan untuk memprediksi variasi variabel dependen (Ghozali, 2012). Pengujian hipotesis dilakukan dengan menggunakan uji signifikansi variabel independen terhadap variabel dependen,

\section{Operasional variabel penelitian}

Operasional variabel penelitian ialah atribut produk $\left(\mathrm{x}_{1}\right)$ dan layanan lembaga pembiayaan $\left(\mathrm{x}_{2}\right)$ sebagai variabel independent, keputusan pembelian $(\mathrm{Y})$ sebagai variabel dependent.

\section{HASIL DAN PEMBAHASAN}

\section{Uji validitas dan reliabilitas}

Pengujian validitas dalam penelitian ini menggunakan metode Moment Product Corelation (Person Corelation). Uji validitas dalam penelitian dilakukan dengan membandingkan nilai $r_{\text {hztung }}$ dengan $r_{\text {tabel }}$ untuk tingkat signifikansi 5 persen dari degree of freedom $(\mathrm{df})=\mathrm{n}-2$, dalam hal ini $\mathrm{n}$ adalah jumlah sample. Jika $r_{\text {hztung }}>r_{\text {tabel }}$ maka pertanyaan atau indikator tesebut dinyatakan valid, begitu juga sebaliknya bila $r_{h z t u n g}<$ $r_{\text {tabel }}$ maka pertanyaan atau indikator tersebut dinyatakan tidak valid. Sedangkan untuk pengujian reliabilitas menggunakan Cronbach's Alpha, dimana suatu instrumen dapat dikatakan handal (reliabel) bila memiliki koefisien keandalan atau alfa 0,60 atau lebih. Suatu variabel dikatakan reliabel apabila hasil Cronbach's Alpha $>0,60$ dan sebaliknya apabila hasil Croncbach Alpha $<0,60$ maka hasil pengujian reliabilitas.

Berdasarkan hasil uji persepsi konsumen menggunakan SPSS 22,0 semua variabel persepsi konsumen dinyatakan valid karena mempunyai koefisien korelasi yang lebih besar dari $\mathrm{r}_{\mathrm{t} \text { abel }}=0,1648$ dan nilai Cronbach's Alpha $>0,60$ dengan kata lain, instrumen penelitian yang berjumlah 28 item pernyataan dalam penelitian ini dinilai valid.

\section{Hasil analisa data}

Analisis regresi linier berganda ini digunakan untuk mengetahui seberapa besar pengaruh variabel pada variabel lainnya. penelitian ini menggunakan variabel independen atribut Produk $\left(\mathrm{X}_{1}\right)$, layanan lembaga pembiayaan $\left(\mathrm{X}_{2}\right)$, dan variabel independen adalah Keputusan Pembelian (Y). Digunakan untuk menganalisis data menghasilkan output seperti yang terlihat pada tabel dibawah ini :

Tabel 3 Hasil Regresi Linier Berganda

\begin{tabular}{|c|c|c|c|c|c|}
\hline \multirow[t]{2}{*}{ Model } & \multicolumn{2}{|c|}{ Unstandardized Coefficients } & \multirow{2}{*}{$\begin{array}{c}\begin{array}{c}\text { Standardized } \\
\text { Coefficients }\end{array} \\
\text { Beta }\end{array}$} & \multirow[t]{2}{*}{$\mathbf{t}$} & \multirow[t]{2}{*}{ Sig. } \\
\hline & B & Std. Error & & & \\
\hline (Constant) & 3,409 & 1,279 & & 2,65 & ,009 \\
\hline Atrbut produk & ,198 & 023 & ,618 & 8,42 &, 000 \\
\hline
\end{tabular}


Layanan lembaga pembiayaan , 156 , 062 , 183 2,50 , 013

a. Dependent Variable: Keputusan Pembelian

Sumber: Data diolah, 2020

Berdasarkan data persamaan regresi tersebut di atas ditunjukkan dengan nilai Standardized Coefficients, dengan pertimbangan bahwa penelitian ini bersifat data kualitatif sehingga dapat dinyatakan dengan persamaan Regresi Linier Berganda berikut ini :

$$
\mathrm{Y}=\mathbf{3 , 4 0 9}+\mathbf{0 , 1 9 8 X 1}+\mathbf{0 , 1 5 9 X 2}
$$

Berdasarkan persamaan regresi linier berganda tersebut, maka dapat diinterpretasikan sebagai berikut :

Konstanta bernilai sebesar 3,409, hal ini menunjukkan bahwa apabila variabel atribut produk dan layanan lembaga pembiayaan bernilai nol (0) maka akan menaikkan keputusan pembelian 3,409.

Koefisien regresi variabel atribut produk $\left(\mathrm{X}_{1}\right)$ sebesar 0,198 menunjukkan bahwa variabel atribut produk berpengaruh terhadap keputusan pembelian (Y). Maka setiap terjadi kenaikan variabel atribut produk sebesar 1 satuan maka akan meningkatkan keputusan pembelian sebesar 0,198. Selain itu, pada variabel atribut produk diperoleh nilai signifikansi sebesar 0,000 . Nilai signifikansi ini lebih kecil dari nilai probabilitas yaitu 0,05 atau $0,000<0,05$. Maka dapat dinyatakan bahwa Ha diterima Ho ditolak. Dengan demikian, pengaruh dari atribut produk (X1) terhadap keputusan pembelian signifikan.

Koefisien regresi variabel layanan lembaga pembiayaan (X2) sebesar 0,159 menunjukkan bahwa variabel layanan lembaga pembiayaan berpengaruh terhadap keputusan pembelian (Y). Maka setiap terjadi kenaikan variabel layanan lembaga pembiayaan sebesar 1 satuan maka akan meningkatkan keputusan pembelian sebesar 0,159 . Selain itu, pada variabel layanan lembaga pembiayaan diperoleh nilai signifikansi sebesar 0,000. Nilai signifikansi ini lebih kecil dari nilai probabilitas yaitu 0,05 atau 0,000 $<0,05$. Maka dapat dinyatakan bahwa Ha diterima Ho ditolak. Dengan demikian, pengaruh dari layanan lembaga pembiayaan (X2) terhadap keputusan pembelian signifikan.

\section{Pengaruh atribut produk dan layanan lembaga pembiayaan terhadap keputusan pembelian}

Berdasarkan hasil uji statistik secara simultan yang telah dilakukan pada penelitian ini menunjukkan bahwa variabel atibut produk dan layanan lembaga pembiayaan $\mathrm{F}_{\text {hitung }}$ sebesar 85,934 dengan signifikansi sebesar 0,000. Berdasarkan hasil tersebut dapat disimpulkan bahwa nilai signifikansi yang diperoleh yaitu $0,000<0,05$ yang berarti variabel atibut produk dan layanan lembaga pembiayaan secara simultan (bersama-sama) berpengaruh positif dan signifikan terhadap keputusan pembelian sepeda motor Honda Vario, di mana hipotesis pertama diterima.

Data responden sebanyak 140 dengan memberikan 17 indikator tentang atribut produk dan 6 indikator tentang layanan lembaga pembiayaan menemukan bahwa ratarata nilai dari setiap indikator adalah baik. Seperti yang kita lihat produk motor Honda Vario yang setiap beberapa tahunnya selalu ada varian terbaru yang mampu memberikan kesan berbeda bagi konsumen. Dalam penelitian ini seperti adanya teknologi injeksi yang ramah lingkungan, sistem brake yang baik dan sein depan dan belakang yang unik menjadi ciri khas dari motor Honda Vario sehingga membangun ketertarikan bagi konsumen untuk memiliki motor Honda Vario. Sesuai dengan Tjiptono (2008) yang menjelaskan bahwa unsur-unsur produk yang dipandang penting oleh konsumen dan dijadikan sebagai dasar pengambilan keputusan pembelian. 
Hal ini sejalan dengan penelitian yang pernah di lakukan oleh Cindy Septiani Putri, 2016 tentang pengaruh atribut produk, promosi penjualan dan kesadaran merek terhadap keputusan pembelian produk motor yamaha pada dealer cahaya yamaha kediri yang menunjukkan bahwa variabel atribut produk berpengaruh positif dan signifikan terhadap keputusan pembelian produk motor yamaha pada dealer cahaya yamaha kediri.

Hasil penelitian ini juga sejalan dengan penelitian yang di lakukan oleh Patria Adi Pradana, 2017 tentang pengaruh atribut produk terhadap keputusan pembelian motor Honda Vario Techno 125 PGM FI di Jakarta Utara juga menujukkan bahwa atribut produk berpengaru positif dan signifikan terhadap keputusan pembelian dan diterima baik oleh konsumen.

Hal ini menjelaskan bahwa layanan lembaga pembiayaan terhadap keputusan pembelian tidak memiliki pengaruh cukup besar terhadap keputusan pembelian. Hal ini bisa juga kita lihat bahwa banyak konsumen yang melakukan pembelian motor Honda Vario secara cash dan tidak menggunakan layanan lembaga pembiayaan sebagai tempat pembiayaan untuk melakukan pembelian sepeda motor Honda Vario di Kota Jambi.

Penelitian ini didukung dengan penelitian yang dilakukan oleh Belly Nomanca (2012) Faktor-faktor yang mempengaruhi keputusan konsumen dalam menggunakan jasa lembaga pembiayaan PT Federal Internasional Finane (FIF) Tanjung Batu Kundur menujukkan bahwa tingkat persepsi konsumen memiliki pengaruh yang signifikan terhadap keputusan konsumen dalam menggunakan jasa lembaga pembiayaan pada PT Federal Internasional Finane (FIF) di Tanjung Batu Kundur. Produk jasa lembaga pembiayaan yang ditawarkan oleh PT. Federal International Finance (FIF) bagi masyarakat pada konsumen yang bertujuan untuk membeli sepeda motor secara kredit. Sebagai perusahaan lemabaga pembiayaan dalam pembelian sepeda motor merek Honda secara kredit PT Federal Internasional Finane (FIF) telah didirikan diberbagai daerah dan termasuk di Kota Jambi. Hal itu membangun ketertarikan dan kemudahan bagi konsumen untuk melakukan pembelian sepeda motor secara kredit karena didukung dengan metode pembayaran yang sangat mudah.

Selain itu penelitian juga dilakukan oleh Haryogi \& Sri (2015) tentang Pengaruh Kualitas Produk dan Kelompok Acuan terhadap Keputusan Pembelian Sepeda Motor Suzuki Satria F150 juga menemukan bahwa sebelum konsumen melakukan pembelian sepeda motor konsumen mempertimbangkan cara pembayaran yang tersedia. Untuk memberikan kemudahan bagi konsumen, pihak suzuki bekerja sama dengan beberapa lemabaga pembiayaan seperti Adira dan FIF agar konsumen dapat membeli produk Suzuki yang diinginkan secara kredit terutama untuk segment menengah kebawah. Dalam hal ini dapat kita simpulkan bahwa cukup besarnya pengaruh layanan lembaga pembiayaan dalam melakukan pembelian sepeda motor. Karena dengan adanya layanan lembaga pembiayaan yang memberikan kemudahan dalam metode pembayaran dan dapat dibayar dimana saja serta prosedur dalam layanan lembaga pembiayaan yang tidak terlalu rumit, lebih mudah dan tidak memakan waktu yang panjang. Hal itulah yang berperan penting meningkatkan untuk dapat melakukan keputusan pembelian sepeda motor Honda Vario.

\section{Pengaruh atribut produk lebih dominan terhadap keputusan pembelian}

Berdasarkan hasil uji statistik secara parsial yang telah dilakukan pada penelitian ini menunjukkan bahwa variabel selebriti atribut produk memiliki nilai signifikansi sebesar 0,000 , di mana lebih kecil dari nilai probabilitas yaitu 0,05 atau sama dengan $0,000<0,05$. Hal ini menunjukkan bahwa variabel atribut produk berpengaruh terhadap keputusan pembelian. Koefisien regresi sebesar 0,198 menunjukkan bahwa variabel 
atribut produk berpengaruh positif terhadap keputusan pembelian sepeda motor Honda Vario.

Begitu pula pada hasil uji statistik secara parsial pada variabel layanan lembaga pembiayaan memiliki nilai signifikansi 0,000 , di mana lebih kecil dari nilai probabilitas yaitu 0,05 atau $0,000<0,05$. Hal ini menunjukkan bahwa variabel layanan lembaga pembiayaan berpengaruh terhadap keputusan pembelian. Koefisien regresi sebesar 0,159 menunjukkan bahwa variabel layanan lembaga pembiayaan berpengaruh positif terhadap keputusan pembelian sepeda motor Honda Vario.

Berdasarkan data di atas, dapat dilihat bahwa antara atibut produk dan layanan lembaga pembiayaan sama-sama memiliki pengaruh terhadap keputusan pembelian sepeda motor Honda Vario. Tetapi, dilihat dari koefisien regresi pada atribut produk lebih tinggi dari layanan lembaga pembiayaan. Artinya variabel atribut produk lebih dominan mempengaruhi keputusan pembelian sepeda motor Honda Vario, di mana hal ini menyatakan bahwa hipotesis kedua diterima.

Atribut produk yang dimiliki oleh Honda Vario dapat diterima dengan baik oleh konsumen yang di tunjukkan dengan adanya pengaruh yang signifikan terhadap keputusan pembelian Honda Vario di Kota Jambi. Atribut produk adalah suatu komponen yang merupakan sifat - sifat produk yang menjamin agar produk tersebut dapat memenuhi kebutuhan dan keinginan yang diterapkan oleh pembeli (Kotler dan Keller, 2009). Dapat diamati produk motor Honda Vario yang setiap beberapa tahunnya selalu ada varian terbaru yang mampu memberikan kesan berbeda bagi konsumen. Dalam penelitian ini seperti adanya teknologi injeksi yang ramah lingkungan, sistem brake yang baik dan sein depan dan belakang yang unik menjadi ciri khas dari motor Honda Vario sehingga membangun ketertarikan bagi konsumen untuk memiliki motor Honda Vario. Sesuai dengan Tjiptono (2008) yang menjelaskan bahwa unsur-unsur produk yang dipandang penting oleh konsumen dan dijadikan sebagai dasar pengambilan keputusan pembelian.

\section{KESIMPULAN DAN SARAN}

\section{Kesimpulan}

Berdasarkan hasil temuan yang di lakukan oleh peneliti, disimpulkan bahwa atribut poduk berpengaruh secara positif dan signifikan terhadap keputusan pembelian konsumen sepeda motor Honda Vario di Kota Jambi.

Berdasarkan hasil temuan yang di lakukan oleh peneliti, disimpulkan bahwa layanan lembaga pembiayaan berpengaruh secara positif dan signifikan terhadap keputusan pembelian konsumen pembelian konsumen sepeda motor Honda Vario di Kota Jambi. Berdasarkan hasil temuan yang dilakukan oleh peneliti, menunjuan bahwa atribut yang berpengaruh dominan terhadap keputusan pembelian sepeda motor Honda Vario di Kota Jambi.

\section{Saran}

Setelah melihat hasil kesimpulan variabel atribut produk dan layanan lembaga pembiayaan dinilai positif oleh konsumen. Untuk itu perusahaan-perusahaan motor Honda di Kota Jambi disarankan untuk terus mempertahankan serta meningkatkan atribut produk yang diciptakan demi meningkatkan penjualan yang diinginkan oleh perusahaan motor Honda dan meningkatkan kualitas layanan lembaga pembiayaan sehingga memberikan ketertarikan konsumen untuk melakukan pembelian motor Honda Vario.

Karena adanya keterbatasan dan kekurangan di penelitian ini, maka diharapkan peneliti selanjutnya dapat memperluas dan mengembangkan penelitian ini dengan 
meneliti faktor lain yang dapat mempengaruhi keputusan pembelian, misalnya harga dan strategi pemasaran perusahaan. Peneliti selanjutnya juga dapat menggunakan metode lain dalam meneliti keputusan pembelian, misalnya melalui wawancara mendalam terhadap responden, sehingga informasi yang diperoleh dapat lebih bervariasi dari pada angket yang jawabannya telah tersedia.

\section{DAFTAR PUSTAKA}

Anis, H. B., \& Lapian, S. J. (2014). Atribut produk dan bauran promosi pengaruhnya terhadap keputusan pembelian sepeda Motor Yamaha Mio. Jurnal EMBA: Jurnal Riset Ekonomi, Manajemen, Bisnis dan Akuntansi, 2(1)

Amri, A. Junaid. Y. (2009). Metodologi penelitian ekonomi dan penerapannya. Bogor: IPB Press.

Arifin, A. (2013). Pendapatan konsumen: faktor utama permintaan kredit sepeda motor pada PT Federal International Finance (Fif) Cabang Purwokerto". In Performance $11(2)$.

Bilson, S. (2001). Memenangkan pasar dengan pemasaran efektif dan prof tabel. Edisi pertama. Jakarta: PT. Gramedia Pustaka Utama

Blaxter, Lorraine, Hughes, Christina, Thight, Malcom (2006). How to research (seluk beluk melakukan riset) edisi ke-2. Jakarta: PT. INDEKS Kelompok Gramedia.

Ghozali, I. (2007). Aplikasi analisis multivariate bagi program SPSS. Badan Penerbit UNDIP. Semarang

Hair, J. Et. All. (1998). Multivariate data analysis. New York: Mc-Grawhill.

Keputusan Menteri Keuangan No.1169/KMK.01/1991 Tanggal 21 September 1991 tentang kegiatan sewa guna usaha

Kotler, P. (2008). Manajemen pemasaran Edisi 12 Jilid 2. Jakarta: Indeks

Kotler, P., Garry, A. (2008). Prinsip-prinsip pemasaran. Edisi 12, Jilid 1. Alih Bahasa: Bob Sabran. Jakarta: Erlangga.

Kotler, P., \& Keller, Kevin L. (2007). Manajemen pemasaran, Edisi 12. Jakarta: Indeks

Khristiawan, I., \& Magnadi, R. H. (2014). Pengaruh citra merek, harga, dan atribut produk terhadap minat beli konsumen pada sepeda motor merek honda (studi kasus pada mahasiswa ekonomi Universitas Diponegoro Semarang) (Doctoral dissertation, Fakultas Ekonomika dan Bisnis).

Lestari, I. A., Kartikowati, S., \& Syabrus, H. (2016). Pengaruh atribut produk dan sikap konsumen terhadap keputusan pembelian sepeda motor honda pada Mahasiswa Universitas Riau. Jurnal Online Mahasiswa (JOM) Bidang Keguruan dan Ilmu Pendidikan, 3(2), 1-11.

Nomanca, B. (2012). Faktor-faktor yang mempengaruhi keputusan konsumen dalam menggunakan jasa leasing Pt. Federal International Finance (Fif) Tanjung Batu Kundur (Doctoral Dissertation, Universitas Islam Negeri Sultan Syarief Kasim Riau).

Pradana, P., \& Relawan, I. (2017). Pengaruh atribut produk terhadap keputusan pembelian honda Vario Techno 125 Pgm Fi di Jakarta Utara. eProceedings of Management, 7(1).

Rahayu, T. (2015). Pengaruh brand equity dan atribut produk motor honda vario terhadap keputusan pembelian melalui nilai konsumen (studi kasus pembeli di Dealer Astra Motor Tegal). Journal of Economic Education, 4(2).

Roza, H. (2012). Analisis penilaian kredit sepeda motor merek honda pada PT. Federal International Finance (Fif) Pekanbaru. Doctoral Dissertation, Universitas Islam Negeri Sultan Syarief Kasim Riau. 
Saragih, R. (2013). Analisis faktor faktor yang mempengaruhi perilaku konsumen dalam menggunakan jasa leasing Pt. Fif (Federal International Finance) Pekanbaru. Doctoral Dissertation, Universitas Islam Negeri Sultan Syarif Kasim Riau.

Setiaji, D. T. (2010). Pelaksanaan perjanjian pembiayaan sepeda motor antara pembeli dengan Pt. Federal International Finance (Fif) Cabang Kota Surakarta. Doctoral Dissertation, Universitas Muhammadiyah Surakarta.

Setiawan, T. (2012). Pelaksanaan perjanjian pembiayaan konsumen sepeda motor pada Pt Federal International Finance (Fif) Cabang Kota Pekanbaru. Doctoral Dissertation, Universitas Islam Negeri Sultan Syarif Kasim Riau.

Suatama, J. (2013). Analisis strategi inovasi atribut produk dan pengaruhnya terhadap keputusan pembelian konsumen pada Skuter Matik Merek Honda Vario di Kota Semarang. Jurnal STIE Semarang, 5(2).

Sugiyono. (2014). Metode penelitian bisnis. Bandung: Alfabeta.

Tjiptono, F. (2008). Strategi pemasaran, edisi 3. Yogyakarta: Andy

Tjiptono, F dan Gregorius C. (2005). Service, quality dan satisfaction, edisi pertama, cetakan kedua, Yogyakarta: Andi,

Krisdianto Tri Wijaksono, 2013, Analisis pengaruh atribut produk sepeda motor Yamaha Mio J (Studi Kasus pada Dealer Yamaha Supriadi Motor di Arjasa-Jember), Jurnal Ekonomi dan Bisnis, 1(2). 